\title{
Definition of the strain-stress distribution of porous glass in the retarded cooling temperature range
}

\author{
Irina Grushko ${ }^{1, *}$ \\ ${ }^{1}$ SRSPU (NPI), Department of Industrial, Civil Engineering, Geotechnics and Foundation Engineering, 346428 Novocherkassk, Russia
}

\begin{abstract}
The estimation of the strain-stress distribution (SSD) of porous glass (foamed slag glass, FSG) is assessed by annealing temperature curves according to the given values of the thermomechanical and thermophysical properties of porous glass, which are in correlation with the properties data of the host glass and its structure. When calculating cooling processes (cooling rate) of porous glass products, the A.N. Dauvalter's formula, which takes into account only the stresses arising from the safe product cooling, but does not take into account those that remained there to the cooling start point, is usually used. The cooling rate in the interval of the annealing zone itself should be sufficiently low so that residual stresses, arising after they pass it, have small values. Since methods, that make it possible to determine the residual stresses that appear in the porous glass after passing through the initial annealing zone, are currently poorly developed, numerical simulation methods should be used to determine the porous glass SSD under the influence of thermal loads. Numerical study of the strain-stress distribution of porous glass allowing for thermal loads in the annealing temperature range was carried out in the Ansys Workbench software package.
\end{abstract}

\section{Introduction}

In industrial and civil engineering thermal insulation materials based on glass and designed to perform effectively the functions of heat protection and the heat accumulation and cold in buildings are of great importance [1]. In conjunction with properties and thermophysical characteristics, porous glass (foam glass) is considered to be promising in use [2]. The powder method of production is the most prevalent in industrial production. It includes four main stages: heating of the foaming mixture (charge), foaming, quenching, annealing. The annealing of the material is aimed to stabilize the structure and to reduce the appearing stresses to acceptable values. It is necessary to note two factors that occur when a temperature changes in a porous glass during its production. When the ambient temperature that surrounds the sample of the porous glass changes, the heat is gradually transferred along the layers of material due to the limited thermal conductivity of the material, so that there will be the temperature difference between the outer and inner layers in the sample. This heat transfer process requires a certain time. The glass matrix of the porous glass changes its linear dimensions when the temperature changes (it expands upon heating and shrinks upon cooling), and, consequently, the layers of material tend to accept the temperature-determined boundaries, which leads to the formation of stresses capable of breaking the sample.

There, in the glass matrix, may appear stresses of the second kind associated with the formation of a crystalline phase. These include the stresses, the appearance of which depends on the presence of the crystallization process in the glass. The resulting crystalline phase has a thermal expansion coefficient different from glass (TCLE). Due to this, there will be a difference between the compression values of the crystal and the glass matrix, which will lead to stresses at the contact boundary. Also, when it comes to improper cooling of the glass, there may occur residual stresses, which reduce the strength of the finished product and subsequently lead to destruction, even after a long time.

Both the structure relaxation process and the stress relaxation process in the glass are well studied and provide the basis for the development of stress analysis methods [3,4]. The calculation of stress relaxation is based on the traditional approach to the solution of viscoelastic problems - using the Boltzmann superposition principle, the validity of the application is confirmed by experimental data $[5,6]$. The finite element method is defined as the most promising for mathematical modeling of heat exchange processes and stress analysis for the desired material at the technological stage of annealing [7].

\section{Object description}

The object (Figure 1) is a sample of a porous glass with dimensions $30 \times 30 \times 30 \mathrm{~mm}$, a perforation coefficient of 0.2589 , an average pore diameter of $3 \mathrm{~mm}$, placed on a $100 \times 100 \times 3 \mathrm{~mm}$ support, 12X18H9T support material [8]. The gas in the pores is $\mathrm{CO}_{2}$.

\footnotetext{
* Corresponding author: grushkois@gmail.com
} 


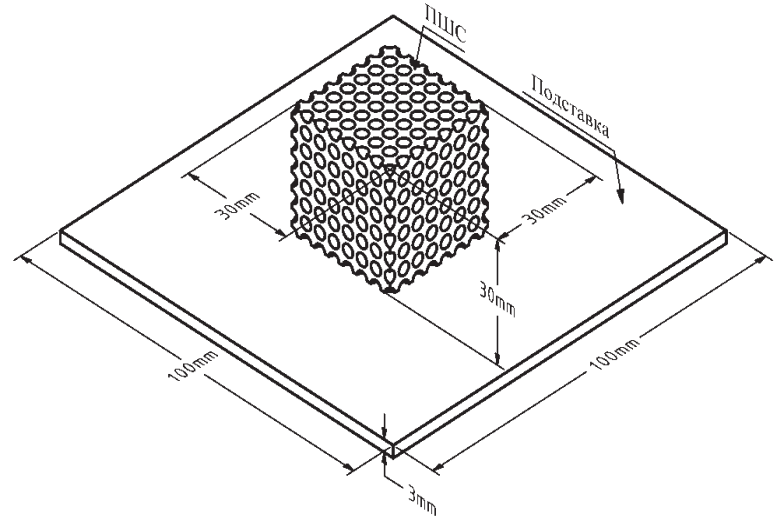

Fig. 1. Study subject

The algorithm for analyzing the strain-stress distribution of a porous glass sample consists in solving the system of equations [9] by the finite element method in the software complex Ansys [10] using the technique proposed in [11], allowing for the relaxation of material properties:

$$
\begin{gathered}
T_{f i}=T-\int_{0}^{t} \exp \left[-\int_{t^{\prime}}^{t} \frac{d t^{\prime \prime}}{\tau_{i}\left(t^{\prime \prime}\right)}\right] \frac{d T\left(t^{\prime}\right)}{d t^{\prime}} d t^{\prime}, \\
T_{f i}=\sum_{i=1}^{n} g_{i \tau} T_{f i}
\end{gathered}
$$

where $\sum_{i=1}^{n} g_{i \tau}=1$,

$$
\begin{gathered}
\lg \tau_{i}=\left(A+\frac{B}{T_{f t}-T_{0}}-\lg K_{i}\right) \frac{T_{f \tau}}{T}-\lg \tau_{0}\left(\frac{T_{f \tau}}{T}-1\right), \\
P=P_{i}\left(T_{f P}\right)+\int_{T_{f P}}^{T}\left(\frac{\partial P}{\partial T^{\prime}}\right) d T^{\prime},
\end{gathered}
$$

where $T$ - temperature, $T_{f}-$ structural temperature, $t$ - time, $\tau$ - relaxation time, $g_{i}$ - weighted coefficients, $n$ - amount of internal parameters characterizing the structure of substance, $A, B$ и $T_{0}$ - constants in the Fulcher-Tamman equation; $P$ - property; $P_{i}$ - property of substance in the equilibrium (liquid) state;

$$
K_{i}=\frac{\eta}{\tau_{i}}
$$

here $\eta$ - viscosity.

Mathematical modeling of the heat transfer process in the study object is based on a numerical solution of the initial boundary value problem:

$$
\begin{aligned}
\rho c \frac{\partial T}{\partial \tau}=\frac{\partial}{\partial x}\left(\lambda_{x} \frac{\partial T(x, y, z, \tau)}{\partial x}\right) & +\frac{\partial}{\partial y}\left(\lambda_{y} \frac{\partial T(x, y, z, \tau)}{\partial y}\right)+ \\
& +\frac{\partial}{\partial z}\left(\lambda_{z} \frac{\partial T(x, y, z, \tau)}{\partial z}\right)
\end{aligned}
$$

where $T(t, x, y, z)$ - desired temperature distribution function; $\lambda_{x}, \lambda_{y}, \lambda_{z}-$ coefficients of thermal conductivity in the direction of the $x, y, z$ axes; $\rho$ - density; $c$ - specific ambient heat.
The stationary heat equation for an isotropic medium has the form:

$$
\operatorname{div}(\lambda \cdot \operatorname{grad} T)=0,
$$

where $T$ - desired temperature distribution function; $\lambda$ - coefficient of thermal conductivity.

In accordance with the peculiarities of the technological mode of the annealing stage, the decrease in the ambient temperature is carried out linearly with a low speed $\left(2-3{ }^{\circ} \mathrm{C} / \mathrm{min}\right)$.

In light of this, the stresses are found from the system of equations of the following form [12]:

$$
\begin{gathered}
\sigma_{i k}=2 G\left[\varepsilon_{i k}+\frac{\mu}{1+\mu} \frac{S}{2 G} \delta_{i k}-\alpha T \delta_{i k}\right] \\
\varepsilon_{i k}=\varepsilon_{k i}=\frac{1}{2}\left(\frac{\partial U_{k}}{\partial x_{i}}+\frac{\partial U_{i}}{\partial x_{k}}\right), i, k=1,2,3, \\
\sum \frac{\partial \sigma_{k i}}{\partial x_{k}}=0
\end{gathered}
$$

where $\sigma_{k i}$-stress, $\left(\sigma_{i i}-\right.$ normal stresses, $\sigma_{k i}(i \neq k)-$ tangential stresses; $\varepsilon_{i k}$ - strains; $U_{i}$ - displacement; $S=\sum \sigma_{i i}-$ sum of the normal stresses, $T-$ ambient temperature, $G$ - shear modulus, $2 G=\frac{E}{(1+\mu)}, E-$ the Young's modulus; $\mu$ - the Poisson's ratio; $\alpha$ - thermalexpansion coefficient; $\quad \delta_{i k}=\left\{\begin{array}{l}1, i=k, \\ 0, i \neq k,\end{array} \quad-\right.$ Kronecker symbol.

The main stages in solving this problem are building a model, setting the initial data, solving and processing the results. It should be noted that the results of calculating the thermal state are the basis for solving the strength problem.

To create geometric models, CAD systems can be used. In this paper we implemented a comprehensive approach to creating a solid model - import of the geometry of a porous glass sample from the $P C$ "GMSH" [13] with subsequent refinement in PC ANSYS (fig. 1).

The process of creating a model of a porous glass sample is automated - the geometry of the sample is formed depending on its size and porosity. The location of the pores is structured - it can have a hexagonal or ordinary arrangement of pores (depends on the thickness of the matrix walls that defines the skeleton of the porous glass); the pore size can be constant with the volume of the sample, or to have random nature. In the presented calculation, pore material is described by a certain number of spherical cavities of small diameter (in the region of $3 \mathrm{~mm}$ ) and a constant composition possessing gas properties.

Work with materials is carried out by the Engineering Data module used to organize and store material data, describe material properties and input parameters of mathematical models using the additional 
interface of the Workbench. When calculating the temperature fields in the Transient Thermal module, the physical properties of materials such as thermal conductivity, heat capacity, etc. are available in the Toolbox window. It is necessary for thermal analysis to set the thermal conductivity in the material properties. The material can be anisotropic or isotropic (orthotropic). For an anisotropic material, the value of the thermal conductivity coefficient does not depend on the direction, i.e. is constant along the $X, Y$, and $Z$ axes, and for the orthotropic material three thermal conductivity coefficients are specified in the $X, Y$, and $Z$ directions.

When performing static strength calculations in the Static Structural module in the Toolbox window the mechanical properties of materials and models are available to describe the behavior of materials under the action of loads (plasticity, creep models, etc.).

To verify the efficiency of the proposed approach to the evaluation of heat transfer in a porous glass, numerical studies of thermal processes in the target material were carried out, the main task of which was to reveal the distribution of the temperature field with the volume of the sample with a change (decrease) in the temperature at the outer boundary of the calculating region (the thermal chamber wall) according to the annealing process. The calculations used real thermophysical and radiative properties of carbon dioxide, a matrix of porous glass and a steel support [14, $15,16,17]$. The values of the thermal conductivity of carbon dioxide at the upper and lower boundary curves, at the critical point and on isobars from 30 to $200 \mathrm{~kg} / \mathrm{cm}^{2}$ to a temperature of $1000{ }^{\circ} \mathrm{C}$ are presented as temperature dependence. The thermal conductivity and the specific heat of the porous glass matrix were determined by the laser flash method [18] in the temperature range $25-700{ }^{\circ} \mathrm{C}$ in the $\mathrm{TC}-9000 \mathrm{H}$ thermal conductivity measuring device at the collective use center "Technologies and Materials of the Belgorod State University", Belgorod. The remaining physical characteristics of the porous glass matrix were chosen in accordance with its chemical composition [8].

The results of the temperature and the strain-stress distribution analyses are made at the calculated points (fig. 2).

The change in temperature over the cross section of the sample (along the lines, fig. 2) for the time point 12000 (the termination of annealing) is shown in fig. 3. The time point corresponds to the temperature at the boundary of the calculated region (furnace wall) of $25^{\circ} \mathrm{C}$. The results of stress analyses are shown in fig. 4 .

\section{Conclusion}

The nature of the change in the temperature field in a sample of porous glass corresponds to the assumptions presented in the literature $[19,20,21]$. The created mathematical model adequately describes the thermal processes and stresses arising in the porous glass at the annealing stage and can be used to create optimal (for energy-consuming) technological processes for the production of porous glass.

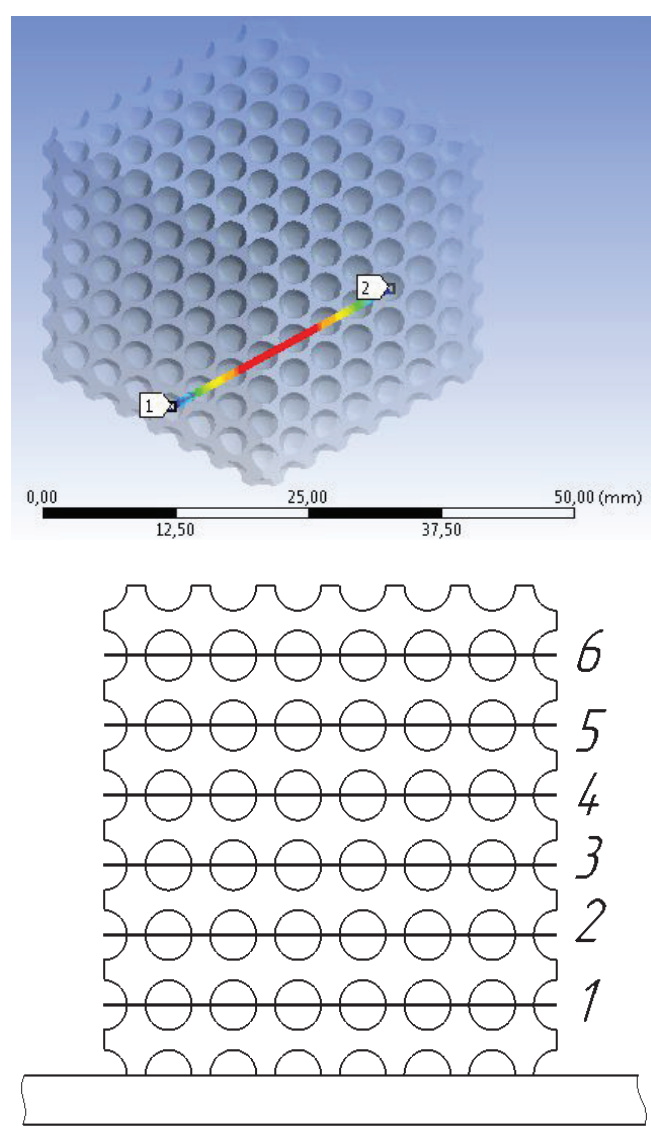

Fig. 2. Location of points and lines of temperature measurement (for example, line 1).

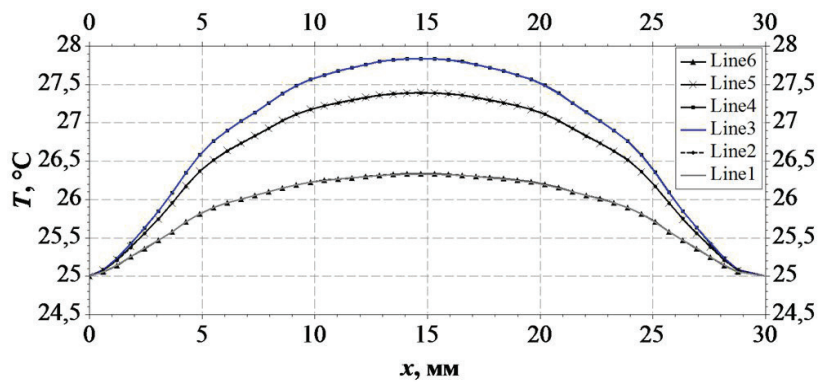

Fig. 3. The change in temperature in the sample at a time point of $12000 \mathrm{~s}$.

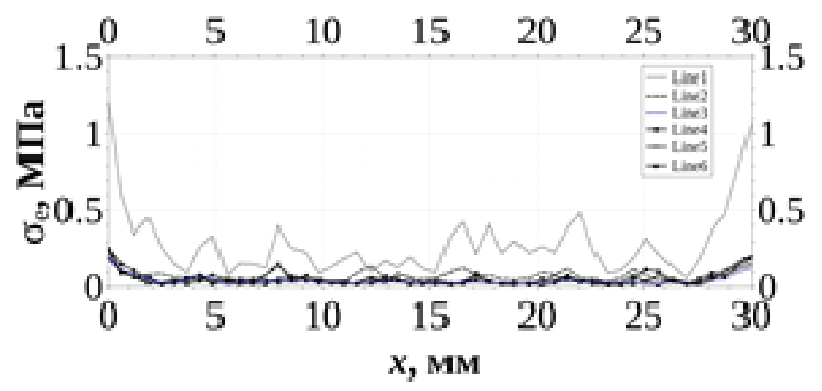

Fig. 4. The voltage magnitude in the sample at time point of $12000 \mathrm{~s}$. 
The article is prepared on the results of a study carried out with the financial support of the Russian Foundation for Basic Research as part of the scientific project No. 16-33-60177 mol_a_dk.

\section{References}

1. N.I. Minko, O.V. Puchka, M.N. Stepanova, S.S. Vaysera, Teploizolyatsionnye materialy. Penosteklo. (Monografiya), Belgorod (2016) [in Russian]

2. M.N. Stepanova, O.V. Puchka, Naukoemkie tekhnologii $i$ innovatsii, sbornik dokladov mezhdunarodnoy nauchno-prakticheskoy konferentsii, 385-389 (2016) [in Russian]

3. O.V. Mazurin, Y.L. Belousov Otzhig i zakalka stekla, 11-21 (1984) [in Russian].

4. E.H. Lee, T.G. Rogers, J. Am. Ceram. Soc, 48 [9] 480-487 (1965)

5. S.M. Rekhson, Y.K. Startsev, Fizika i himiya stekla, 2, 140-1486 (1977) [in Russian]

6. V.P. Klyuev, A.S. Totesh, Metody $i$ apparatura dlya kontrolya vyazkosti stekla, (VNIIEHSM, Moscow, 1975) [in Russian]

7. I.S. Grushko, Steklo i keramika, 10, 3-9 (2016) [in Russian]

8. I.S. Grushko Razrabotka teploizolyatsionnogo steklo- $i$ steklokristallicheskogo kompozita stroitelnogo naznacheniya na osnove zoloshlakovyh othodov, Cand. tech. sciences. Diss., South-Russian State Polytechnic University (NPI), St. Petersburg (2015) [in Russian]

9. O.V. Mazurin, Steklovanie, (Nauka, Leningrad, 1986)

10. N.N. Fedorova, S.A. Valger, M.N. Danilov, Y.V. Zaharova, Osnovy raboty v ANSYS 17, (DMK Press, Moscow, 2017)

11. O.Y. Smetannikov, N.A. Trufanov Vychislitelnaya mekhanika sploshnyh sred, 1, 92-107 (2008) [in Russian]

12. E. Melan, G. Parkus, Termouprugie napryazheniya vyzvannye statsionarnymi temperaturnymi polyami (Fizatgiz, Moscow, 1958) [in Russian].

13. GMSH Reference Manual. Gmsh 3.0., available at: http://gmsh.info/doc/texinfo/gmsh.html (2017) [in Russian]

14. GSSSD 101-86 Dioksid ugleroda. Koehffitsienty vyazkosti, teploprovodnosti $i$ chislo Prandtlya razrezhennogo gaza $v$ diapazone temperatur $150 \ldots 2000 \mathrm{~K}$, Tablitsy spravochnyh standartnyh dannyh (Izd-vo standartov, Moscow, 1986) [in Russian].

15. N.V. Tsederberg, Teploprovodnost gazov $i$ zhidkostey (Gosenergoizdat, Moscow - Leningrad, 1963) [in Russian].

16. L.N. Latyev, V.A. Petrov, V.Y. Chekhovskiy, E.N. Shestakov Izluchatelnye svoystva tverdyh materialov: spravochnik (Energiya, Moscow, 1974) [in Russian]
17. A. Misnar, Teploprovodnost tverdyh tel, zhidkostey, gazov $i$ ih kompozitsiy, (Mir, Moscow, 1968) [in Russian]

18. V.G. Baranov, A.V. Tenishev, A.V. Lunev, S.A. Pokrovskiy, A.V. Hlunov, Yadernaya fizika $i$ inzhiniring, 2(4), 291-302 (2011) [in Russian].

19. I.I. Kitaygorodskiy, Penosteklo: uchebnoe posobie, Stroyizdat ,Moscow, 1958) [in Russian].

20. B.K. Demidovich, Penosteklo (Nauka i tekhnika, Minsk, 1975) [in Russian].

21. S.V. Alekseev Sovershenstvovanie protsessa otzhiga vysokoporistyh materialov na osnove stekla (Belgorod Shukhov State Technological University, Belgorod, 2002) [in Russian] 